\title{
Effect of growth hormone and growth media on the rooting and shooting of Zanthoxylum armatum stem cuttings
}

\author{
N. Phuyal ${ }^{1 \& 2^{*}}$, P. K. Jha ${ }^{1}$, P. P. Raturi ${ }^{3}$, S. Gurung ${ }^{3}$ and S. Rajbhandary ${ }^{1}$
}

The common method of propagation is through seeds but seed germination in Zanthoxylum armatum is very low due to the presence of hard seed coat, which might be a great hurdle for large scale production of plantlets. So an attempt was made in this study to see the effect of different growth hormones, their concentrations and different rooting media on the rooting and sprouting of $Z$. armatum. The stem cuttings of $Z$. armatum were treated with two types of auxins namely Indole-3-Butyric Acid (IBA) and Naphthalene Acetic Acid (NAA) at different concentrations (2000 ppm, 3000 ppm and $5000 \mathrm{ppm}$ ), while the untreated cuttings were used as control. The cuttings were planted in three different rooting media: sand, neopeat and mix (containing a mixture of sand, soil and vermin-compost). The completely randomized design was used for the experiment. The total number of stem cuttings of $Z$. armatum used in the experiment was 1080 for 18 treatments in three replicates (20 cuttings per treatment $x 18$ treatments $\times 3$ replicates). The experiment was set up in controlled greenhouse conditions at Dabur Nepal Private Limited Nursery, Banepa, Kavre District. The parameters evaluated were root length, shoot length and number of roots per cutting. The collected data were analyzed statistically using R-program with Agricola. Least significant difference (LSD) and Duncan multiple Range Test (DMRT), as mean separation technique was applied to identify the most efficient treatment in the rooting and shooting behavior of $Z$. armatum (Gomez and Gomez, 1984). Hormone concentration and growth media significantly affected the rooting and shooting ability of $Z$. armatum stem cuttings. IBA was found to be more effective than NAA. Neopeat medium was better than sand and mix media. The highest number of roots (6.5) and root length $(11.6 \mathrm{~cm})$ were recorded under IBA $5000 \mathrm{ppm}$ in neopeat medium.

Key words: growth hormones, growth media, sprouting, stem cuttings, rooting, Zanthoxylum armatum,

$P_{\mathrm{p}}^{\mathrm{p}}$ anthoxylum armatum DC. (Eng. winged prickly ash; Nep. Timur) belonging to family Rutaceae, is a popular Nepalese spice plant (Manandhar, 2002). The plant is an erect shrub or a small tree up to $6 \mathrm{~m}$ in height with dense glabrous foliage and straight prickles on stem, commonly occurring in hot valleys of subtropical to temperate Himalayas (Kashmir to Bhutan), north-east India and Pakistan, Laos, Myanmar, Thailand, China, Bangladesh, Bhutan, Japan, North and South Korea, North Vietnam, Taiwan, Lesser Sunda Islands, Philippines, Malaya peninsula and Sumatra
(Grierson and Long, 1991; Nair and Nayar, 1997). In Nepal, it is distributed from west to east at an elevation range of 1000 to $2500 \mathrm{~m}$ in open places or in forest undergrowth (DPR, 2007). It is an important medicinal plant with a high trade value having diverse uses in Ayurveda, pharmacy and industry. It has been used in several traditional medicinal practices to cure several diseases such as abdominal pain, carminative, antispasmodic, rheumatism, skin diseases, cholera, diabetes and asthma (Singh et. al, 2016). Among the eight species of Zanthoxylum found in Nepal, $Z$. armatum is the most common and one of the

\footnotetext{
Central Department of Botany, Tribhuvan University, Kirtipur, Kathamndu, Nepal. * E-mail: nirmalaphuyal@gmail.com

Department of Plant Resources, Ministry of Forests and Environment, Thapathali, Kathmandu, Nepal.

Ashok Medicinal and Aromatic Plants Center, Dabur Nepal Pvt. Ltd., Janagal, Kavre, Nepal.
} 
30 medicinal plants and it is prioritized by the government for cultivation and agro-technology development (DPR, 2006).

The plant grows well in open pastures, degraded slopes, shrub lands, natural forests and wastelands with adequate rainfall, deep soils exposed to sun. Clay or loam soil with high organic matter is suitable for the cultivation of this species. The flowering starts in five year old plants in AprilMay and fruiting in August-October and can be harvested from October to January (Anonymous, 2008). The plants are ready to harvest after three years of plantation and the average annual yield of five years old plant is about $3.5 \mathrm{~kg}$ (ANSAB, 2011). Z. armatum is generally free from disease, insect or nematode attack; however seven insect pests mostly causing defoliation were reported by Tara et al. (2011).

The growing demand of $Z$. armatum in both domestic and international markets, unsustainable harvesting from the wild and lack of proper conservation strategies have led to a sharp decline in the natural population of this valuable plant (Phuyal et al., 2018). The common method of propagation is through seeds but seed germination in Z. armatum is very low due to the presence of hard seed coat (Chadha, 1976) which might be a great hurdle for large scale production of plantlets. Furthermore the solitary seeds in the fruit also limit the quantities of seed in Z. armatum (Singh and Rawat, 2017). Hence vegetative propagation through stem cuttings could be a viable option for mass scale nursery production of quality planting materials of required genotypes. The increased genetic gains through mass propagation have been obtained in several horticultural plants (Leakey et al., 1994; Poupard et al., 1994; Swamy et al., 2002). However, root initiation in cuttings is affected by various factors like plant growth regulators, age of the plant, growth media, size of the cuttings (Hartmann et al., 2002; Husen and Pal, 2006).

The information on the propagation techniques of $Z$. armatum is still meager. Therefore a low cost and reliable technology for the propagation for $Z$. armatum has to be developed to integrate its manifold applications into agroforestry systems for the overall benefit of the rural communities as well as the ex-situ and in-situ conservation of this important plant. Commercial farming by developing suitable agro-technology could be very crucial for enhancement of the marginalized and disadvantaged rural communities. Hence an attempt was made in this study to see the effect of different growth hormones, their concentrations and different rooting media on the rooting and sprouting of $Z$. armatum.

\section{Materials and methods}

The study was conducted at the green house of Dabur Nepal Nursery Private Limited, Banepa during February 2017.

\section{Collection of plant materials}

Fresh branches were collected from 4-5 years old healthy plants of $Z$. armatum grown at the Nursery premises. The semi-hard wood branches were cut into $15 \mathrm{~cm}$ long segment with 2-3 nodes, and all the leaves were removed.

\section{Surface sterilization}

All the selected cuttings were surface sterilized by soaking in freshly prepared $1 \%$ Bordeaux mixture (Calcium Hydroxide and Copper Sulphate) for 10-15 minutes.

\section{Hormone concentration}

Different concentrations i.e. 2000, 3000 and 5000 ppm of two plant growth hormones IBA and NAA were prepared according to the procedure described by Hartmann et al. (2002). The surface sterilized cuttings (cut ends only) were then dipped in a bucket containing the respective hormones solutions for 24 hours so as to enhance the absorption of hormones.

\section{Growth media}

Three different growth media (rooting media) viz. sand, neopeat (coconut fiber) and mix (containing a mixture of sand, soil and vermi-compost, in the proportion of 2:1:1) were used for studying the rooting behavior of $Z$. armatum. After dipping in hormones, the cuttings were planted directly into the rooting media. Plastic trays (No.21) having 20 cells/cavities and holes at the bottom were used for planting the cuttings. The length and breadth of the tray are $54 \mathrm{~cm}$ and $28 \mathrm{~cm}$, respectively. The length of each cell is $6.8 \mathrm{~cm}$ whereas the top diameter is 6 $\mathrm{cm}$ and the bottom diameter is $2.7 \mathrm{~cm}$. The cavities 
in the trays were filled with the respective rooting media. A single cutting per cavity was inserted obliquely up to a depth of $3 \mathrm{~cm}$.

\section{Experimental design}

The completely randomized design was used for the experiment. The total number of stem cuttings of $Z$. armatum used in the experiment was 1080 for 18 treatments in three replicates (20 cuttings $\mathrm{x} 18$ treatments $\mathrm{x} 3$ replicates). Hundred cuttings treated with Bordeaux mixture and washed with distilled water were used as control.

\section{Growth conditions}

After planting the cuttings, all the planting trays were labeled clearly and they were transferred to the green house and placed in the controlled environment. The temperature and relative humidity were maintained at $21.9^{\circ} \mathrm{C}$ and $75 \%$, respectively throughout the research/study period. Inside the greenhouse, agro-meteorological parameters were recorded through the sensor system run by ARGUS Control and the data were recorded in the computer. Relative humidity was maintained through misting.

\section{Data collection}

Numbers of roots, root length and shoot length of individual cutting was recorded after 90 days of planting. A cutting was considered to be rooted if it had at least one primary root of about $1 \mathrm{~mm}$ long. For measurement, the cutting was uprooted gradually and then it was cleared off the rooting media carefully so that the roots do not get damaged. The number of primary roots was counted and root and shoot length were measured with a ruler.

\section{Statistical analysis}

The collected data were analyzed statistically using R-program with Agricola. Least significant difference (LSD) and Duncan multiple Range Test (DMRT), as mean separation technique was applied to identify the most efficient treatment in the rooting and shooting behavior of $Z$. armatum (Gomez and Gomez, 1984).

\section{Results and discussion}

Both growth hormones, IBA and NAA at different concentrations and different growth media viz. sand, mix and neopeat had a significant effect $(p<0.05)$ on the number of roots, length of roots and shoots of stem cuttings of $Z$. armatum. The values obtained for IBA and NAA were close to each other (Table 1), however, IBA was found to be more effective than NAA and neopeat was the best growth medium as compared to sand and mix media (Table 3). Furthermore, the measured values (root length, shoot length and number of roots) showed steady increment with the increase in concentration of the growth hormones from $2000 \mathrm{ppm}$ to $5000 \mathrm{ppm}$. But for NAA, the values increased from $2000 \mathrm{ppm}$ to $3000 \mathrm{ppm}$ concentration and decreased in $5000 \mathrm{ppm}$ concentration except for number of roots, which was the highest in concentration $5000 \mathrm{ppm}$ of NAA. Similarly, the shoot length for concentration 3000 of IBA was lower than concentration $2000 \mathrm{ppm}$ (Table 2). IBA produced more number of roots per cutting as compared to NAA as well as the root and shoot lengths were also longer in IBA than NAA. The values obtained in the treated groups were relatively higher than those of the untreated groups (control).

The number of roots per cutting was affected by the type and concentration of growth hormones and the different growth media but not by the interaction between hormone concentration and growth media. The number of roots produced by IBA and NAA are not significantly different. The value is 4.6 for IBA and 4.4 for NAA (Table 1). The concentration $5000 \mathrm{ppm}$ of IBA had the highest mean number of roots i.e. 5.9,

Table 1: Effect of different hormones on the rooting and shooting of $Z$. armatum stem cuttings

\begin{tabular}{|l|c|c|c|}
\hline Growth hormones & Root length $(\mathbf{c m})$ & Shoot length $\mathbf{( c m )}$ & Number of roots \\
\hline IBA & $9.0 \mathrm{a}$ & $28.0 \mathrm{a}$ & $4.6 \mathrm{a}^{*}$ \\
\hline NAA & $8.1 \mathrm{a}$ & $25.3 \mathrm{~b}$ & $4.4 \mathrm{a}$ \\
\hline Control & $5.4 \mathrm{~b}$ & $22.0 \mathrm{c}$ & $2.4 \mathrm{~b}^{*}$ \\
\hline
\end{tabular}

Means with the same letter in the same column are not significantly different $(\mathrm{P} \geq 0.05)$. 
Table 2: Effects of hormone concentrations on $Z$. armatum stem cuttings

\begin{tabular}{|l|c|c|c|}
\hline Hormone concentration & Root length (cm) & Shoot length (cm) & Number of roots \\
\hline IBA2000 & $7.6 \mathrm{~b}$ & $28.6 \mathrm{a}$ & $3.4 \mathrm{c}$ \\
\hline IBA3000 & $8.3 \mathrm{~b}$ & $26.8 \mathrm{~b}$ & $4.5 \mathrm{~b}$ \\
\hline IBA5000 & $11.3 \mathrm{a}$ & $28.7 \mathrm{a}$ & $5.9 \mathrm{a}$ \\
\hline NAA2000 & $7.6 \mathrm{~b}$ & $25.9 \mathrm{~b}$ & $3.2 \mathrm{~b}$ \\
\hline NAA3000 & $9.8 \mathrm{a}$ & $26.1 \mathrm{~b}$ & $4.3 \mathrm{c}$ \\
\hline NAA5000 & $6.9 \mathrm{~b}$ & $23.9 \mathrm{c}$ & $5.2 \mathrm{a}$ \\
\hline Control & $5.4 \mathrm{c}$ & $22.0 \mathrm{c}$ & $2.4 \mathrm{c}$ \\
\hline
\end{tabular}

Means with the same letter in the same column are not significantly different $(P \geq 0.05)$.

while control had the least mean number of roots i. e. 2.4 (Table 2). Likewise, the maximum average number of roots was 5 in the growth medium neopeat, while it was 4.2 in sand (Table 3 ). On the other hand, the highest number of roots was observed in the interaction of concentration $5000 \mathrm{ppm}$ of IBA with neopeat medium with an average of 6.5 and the lowest value was 2 for the interaction between control and sand (Table 4).

Hormone concentration had significant effect on the root length of $Z$. armatum stem cuttings. The concentration $5000 \mathrm{ppm}$ of IBA had the longest root length $(11.3 \mathrm{~cm})$ and control had root length of $5.4 \mathrm{~cm}$ (Table 2). There was no significant effect of growth media and interaction between hormone concentration and growth media. The interaction between hormone concentration and growth media showed that the concentration $5000 \mathrm{ppm}$ of IBA with neopeat and mix media had the highest mean length of root of $11.6 \mathrm{~cm}$ each, while the least value was $5 \mathrm{~cm}$ for control in sand (Table 4). Among the growth media, neopeat had the longest mean root length of $9.2 \mathrm{~cm}$, while the least value was $8.3 \mathrm{~cm}$ for sand (Table 3 ).

The length of shoots was not significantly affected by different growth media and the interaction between different hormone types and concentration. The highest mean shoot length $(27 \mathrm{~cm})$ was in neopeat, while it was $26.4 \mathrm{~cm}$ in both sand and mix media (Table 3). Similarly the interaction between growth media and hormone concentration had the highest shoot length $(29.7 \mathrm{~cm})$ in the combination of IBA $2000 \mathrm{ppm}$ and neopeat and the lowest mean shoot length of $21.2 \mathrm{~cm}$ in control with sand (Table 4). On the other hand, the different hormone types and concentration had significant effect on the shoot length. IBA had the highest mean shoot length $(28 \mathrm{~cm})($ Table 1) and IBA $5000 \mathrm{ppm}$ had the best effect on the shoot length with a mean value of $28.7 \mathrm{~cm}$ (Table 2).

Table 3: Effects of rooting media on the performance of $Z$. armatum stem cuttings

\begin{tabular}{|l|c|c|c|}
\hline \multicolumn{1}{|c|}{ Growth media } & Root length (cm) & Shoot length (cm) & Number of roots \\
\hline Sand & 8.3 & 26.4 & $4.2 \mathrm{~b}$ \\
\hline Neopeat & 9.2 & 27.0 & $5.0 \mathrm{a}$ \\
\hline Mix & 8.8 & 26.4 & $4.4 \mathrm{ab}$ \\
\hline
\end{tabular}

Means with the same letter in the same column are not significantly different $(P \geq 0.05)(n s$ : not significant) 
Table 4: Interaction of hormone concentration and growth media on $Z$. armatum stem cuttings

\begin{tabular}{|c|c|c|c|c|c|c|c|c|c|}
\hline \multicolumn{10}{|c|}{ Growth media } \\
\hline & \multicolumn{3}{|c|}{ Root length (cm) } & \multicolumn{3}{|c|}{ Shoot length $(\mathrm{cm})$} & \multicolumn{3}{|c|}{ Number of roots } \\
\hline & Sand & Neopeat & Mix & Sand & Neopeat & Mix & Sand & Neopeat & Mix \\
\hline \multicolumn{10}{|c|}{ Hormone Concentration } \\
\hline IBA2000 & 6.9 & 8.0 & 8.0 & 28.8 & 29.7 & 27.8 & 2.7 & 3.3 & 3.8 \\
\hline IBA3000 & 8.5 & 9.1 & 7.4 & 27.5 & 27.2 & 25.8 & 3.8 & 5.1 & 4.8 \\
\hline IBA5000 & 10.7 & 11.6 & 11.6 & 28.2 & 28.5 & 29.0 & 5.5 & 6.5 & 5.6 \\
\hline NAA2000 & 7.4 & 7.1 & 8.3 & 26.0 & 25.4 & 26.3 & 4.5 & 5.8 & 5.0 \\
\hline NAA3000 & 7.0 & 11.3 & 11.3 & 26.3 & 27.3 & 24.8 & 4.4 & 5.9 & 3.7 \\
\hline NAA5000 & 7.0 & 8.2 & 5.4 & 22.1 & 25.0 & 24.4 & 3.9 & 3.4 & 3.2 \\
\hline Control & 5.0 & 5.8 & 5.5 & 21.2 & 22.6 & 22.4 & 2.0 & 2.3 & 2.9 \\
\hline
\end{tabular}

There were significant differences in effect of different concentrations of IBA and NAA and different growth media (sand, neopeat and mix) on the rooting and shooting of stem cuttings of $Z$. armatum.. The exogenous application of growth hormones to induce rooting on stem cuttings has been widely established by several researches (Leakey et al., 1994; Poupard et al., 1994; Hartman et al., 2002; Tchoundjeu et al., 2004). The widely used sources of growth hormones for rooting stem cuttings are the different types of auxins: IAA, IBA and NAA, which are known to increase the rate of rooting as well as number of roots per cutting (Gehlot et al., 2014; Ibrahim et al., 2015).

Auxins are responsible for the overall development in plants from cell division to cell expansion (Taiz and Zeiger, 1998). The initial cell division during root formation in the cuttings depends on the level of auxins, be it exogenous or endogenous (Ludwig, 2000; Kochhar et al., 2005). In this experiment also, IBA and NAA had a significant effect on the number of roots per cutting as well as the length of the roots and shoots as compared to the untreated groups. This might be due to the accumulation of metabolites at the auxins application site, cell enlargement, enhanced hydrolysis of carbohydrates, synthesis of new proteins, and cell division (Strydem and Hartman, 1960). IBA was found to be more effective than NAA in enhancing root formation. The exogenous application of adequate IBA might have caused the vascular differentiation of cells and production of more number of roots. Increase in length of the roots and shoots at higher concentrations might be due to the early formation of roots and more utilization of the nutrients (Banjara, 2017).

The effectiveness of IBA in enhancing root proliferation as well as root numbers have been well documented by several earlier studies in different species. The cuttings of Jatropha curcas treated with IBA had the highest mean number of roots than cuttings treated with NAA (Adekola and Akpan, 2012). The highest rooting rate was obtained in Aesculus indica cuttings treated with IBA (Majeed et al., 2009). Stereospermum suaveolens cuttings produced the longest root with IBA (Baul et al., 2008). Similar results were obtained for the cuttings of Shorea leprosula (Aminah et al., 1995), Ulmus villosa (Bhardwaj and Mishra, 2005), Lippia javanica (Soundy et al., 2008), Buchholzia coriacea (Akinyele, 2010), Ficus hawaii (Hassanein, 2013), Massularia acuminate (Usman and Akinyele, 2015), Cyclopia subternata (Mabizela et al., 2016) and Toona ciliata (Thakur et al., 2018).

Among the different concentrations of IBA, 5000 ppm showed the best result in both rooting and shootings of $Z$. armatum stem cuttings. This is in accordance with the findings of Daudi et al. (2016), who conducted propagation techniques in Z. alatum through stem cuttings and seed germination. They found that the cuttings treated with the concentration $5000 \mathrm{ppm}$ of IBA exhibited better sprouting and rooting than the concentrations $4000 \mathrm{ppm}$ and $6000 \mathrm{ppm}$ of IBA. They also concluded that propagation from the stem cuttings is more suitable than seed sowing for $Z$. armatum because seed germination process 
is very slow in the species. Similar results were obtained by Singh and Rawat (2017) in $Z$. armatum semi-hard wood (SHW) and hard-wood (HW) branch cuttings. IBA at $0.3 \%$ and $0.4 \%$ concentrations exhibited greater success in root and shoot growth, whereas lower concentrations completely failed to root.

Several studies have demonstrated the better rooting ability of IBA at higher concentrations. Majeed et al. (2009) proved that IBA at $4000 \mathrm{ppm}$ concentration is an optimal plant growth regulator for rooting the cuttings of Aesculus indica. High rooting rate was obtained for Celtis australis cuttings treated with $3000 \mathrm{ppm}$ IBA (Shameet et al.. 1989). Dalbergia sisso and Dalbergia latifolia also exhibited a very high rooting rate with the application of the concentration $5000 \mathrm{ppm}$ of IBA (Sharma and Pandey, 1999). Maximum number of roots was produced in Melissa officinalis stem cuttings at 5000 ppm concentration of IBA (Sevik and Guney, 2013).

Thakur et al. (2018) concluded that the cuttings of Toona ciliata produced significantly maximum average length of sprouts, root and number of roots per cutting with the application of $8000 \mathrm{ppm}$ of IBA in comparison to other formulations. The apical cuttings of Berberis aristata treated with $5000 \mathrm{ppm}$ of IBA concentration demonstrated significantly better rooting and sprouting compared to other treatments (Ali et al., 2008). The higher concentration of IBA is required to compensate the low endogenous levels of auxin in the mature cuttings, otherwise difficult to root species like Terminalia arjuna (Banjara, 2017).

The growth medium or the rooting medium is one of the major factors affecting the rooting of stem cuttings (Ingram et al., 1993). The rooting success in any cutting is affected by the interaction of a number of factors like water, oxygen, and nutrient availability in the growth media (Alikhani et al., 2011; Bhardwaj, 2014). The effect of growth media on the rooting ability of stem cuttings of several economically important plants have been demonstrated by several works (Wojtusik et al., 1994; Tchoundjeu et al., 2002; Akinyele, 2010; Jacygrad et al., 2012; Usman and Akinyele, 2015; Ibironke and Victor, 2016).

The results obtained in this study revealed that there was a significant effect of growth media on the root number, root length and the shoot length of $Z$. armatum stem cutings. The highest values were observed in neopeat medium and the lowest values in sand medium. Neopeat medium had more number of roots and the longest roots than sand and mix media. Sand is too porous and cannot retain water for a longer period of time as well as low in nutrient content whereas the neopeat consists of mixture of all the required nutrients, better aeration and adequate drainage (Akinyele, 2010). Poor aeration in waterlogged conditions may lead to decay of cuttings before root initiation (Schmitz et al., 2013).

This corroborated with the findings of Tchoundjeu et al. (1998) in the cuttings of Prunus africana, which rooted better in sawdust than in sand. Similar findings were described by Wojtusik et al., 1994 in Prosopis juliflora cuttings, which produced more number of roots and the longest roots in perlite medium than in compost medium. Therefore to enhance steady rooting, the best quality hormone and rooting media is crucial.

\section{Conclusion}

As the seed germination rate is very slow in $Z$. armatum, vegetative propagation through stem cuttings is a viable option for the mass production of elite plant materials. This study evaluated the effect of different growth hormone types, concentration and growth media on the rooting and shooting performance of $Z$. armatum stem cuttings. The results showed that growth media and hormonal concentration significantly affect the growth of root, shoot and the number of roots of $Z$. armatum stem cuttings. Both IBA and NAA responded well in rooting and shooting but IBA was found to be effective as compared to NAA. Among the various concentrations of IBA, 5000 ppm showed the best performance in terms of average root length, shoot length and number of roots per cutting. Similarly, the neopeat growth medium was found to be superior over the sand and mix media. So it can be concluded from this study that IBA $5000 \mathrm{ppm}$ concentration with neopeat medium is the best treatment for rooting the stem cuttings of $Z$. armatum. The results obtained in this study could be of relative significance for the commercial production of quality plantlets as well as for improving agroforestry systems. 


\section{Acknowledgements}

The first author is thankful to Dabur Nepal for the grant "Dabur CSR Fellowship (Late Sri Ashok Chand Burman) 01/2016'. We are thankful to the staff of Dabur Nepal Private Limited Nursery for their various help in conducting the experiment. Special thanks to Mr. Mohan Mahato from CIMMYT, Nepal for his valuable assistance in statistical analysis. Sincere thanks to Prof. Dr. Mohan Siwakoti, Head, Central Department of Botany, Tribhuvan University for his encouragement. We are thankful to Mr. Kiran Kumar Pokharel from the Forest Research and Training Center for his help and support.

\section{References}

Adekola, O. F. and Akpan, I. G. 2012. Effects of growth hormones on sprouting and rooting of Jatropha curcas L. stem cuttings. Journal of Applied Science and Environment Management 16(1):153-156.

Akinyele,A. O. 2010. Effects of growth hormones, rooting media and leaf size on juvenile stem cuttings of Buchholziacoriacea Engler. Annals of Forest Research 53 (2): 127-133.

Ali, M., Malik, A. R. and Sharma, K. R. 2008. Vegetative propagation of Berberis aristata DC. An

endangered Himalayan shrub. Journal of Medicinal Plants Research 2 (12): 374377.

Alikhani, L., Ansari, K., Jamnezhad, M., Tabatabaie, Z. 2011.Effect of different media and cuttings on growth and rooting of pomegranate cuttings. Iranian Journal of Plant Physiology 1 (3): 199-203.

Aminah, H., Dickb, J. M. P., Leakey, R. R. B., Grace, J. and Smith, R. I. 1995. Effect of indole butyric acid (IBA) on stem cuttings of Shorea leprosula. Forest Ecology and Management 72: 199-206.

Anonymous. 2008. Agro-techniques of Selected Medicinal Plants (Vol. 1). National Medicinal Plants Board, New Delhi, India.
ANSAB. 2011. Enhancing Livelihood and Reducing Poverty of Mountain People by Linking High Value Product and Services. Value Chain Development Project, Final Progress Report, ANSAB, Kathmandu.

Banjara, K., Swamy, S. L. and Singh, A. K. 2017. Vegetative propagation of Terminalia arjuna (Roxb.) WT. \& ARN. by stem cuttings under mist. International Journal of Agriculture Sciences 9 (50): 4847-4850.

Baul, T. K, Mezbahuddin, M. and Mohiuddin M. 2008. Vegetative propagation and initial growth performance of Stereospermum suaveolens $\mathrm{DC}$, a wild tropical tree species of medicinal value. New Forests 37 (3): $375-283$.

Bhardwaj, D. R. and Mishra, K. 2005. Vegetative propagation of Ulmus villosa: effects of plant growth regulators, collection time, type of donor and position of shoot on adventitious root formation in stem cuttings. New Forests 29: 105-116. DOI 10.1007/s11056-005-0240-1.

Bhardwaj, R. L. 2014. Effect of growing media on seed germination and seedling growth of papaya cv. 'Red Lady'. African Journal of Plant Science 8 (4) : 178-184.

Chadha, Y. R. 1976. The Wealth of India - Raw Materials. The Wealth of India 11. Council of Scientific and Industrial Research: New Delhi.

Daudi, P., Bisht, K. S. and Pandey, B. 2016. Propagation techniques of Zanthoxylum alatum Roxb. (a Himalayan toothache shrub). Current Science 110 (1): 30-33.

DPR. 2006. Nepal Ko Aarthik Bikaska Lagi Prathamikta Prapta Jadibutiharu (in Nepali). Department of Plant Resources (DPR), Kathmandu, Nepal.

DPR.2007. Medicinal Plants of Nepal (Revised edition). (Vol. 28). Bulletin of Department of Plant Resources (DPR), Thapathali, Kathmandu, Nepal.

Gehlot, A., Gupta, R. K., Tripathi, A., Arya, I. 
and Arya, S. 2014. Vegetative propagation of Azadirachta indica: effect of auxin and rooting media on adventitious root induction in mini-cuttings. Adv in For. Sci. 1 (1): 106-115.

Gomez, K. A, and Gomez, A. A. 1984. Statistical Procedures for Agricultural Research, 2nd edn, vol xvi. Wiley, New York.

Grierson, A. J. C. and Long, D. G. 1991. Flora of Bhutan. Volume 2 Part 1. Royal Botanic Garden, Edinburgh.

Hassanein, A. M. A. 2013. Factors influencing plant propagation efficiency via stem cuttings. Journal of Horticultural Science \& Ornamental Plants 5 (3) : 71-76.

Hartmann, H. T., Kester, D. E., Davies, F. T. and Geneve, R. L. 2002. Plant propagation: principles and practices ( $7^{\text {th }}$ ed.). Prentice Hall, Inc.: Upper Saddle River, New Jersey, USA.

Husen, A., and Pal, M. 2006. Variation in shoot anatomy and rooting behaviour of stem cuttings in relation to age of donor plants in teak (Tectona grandis Linn. f.). New Forests 31 (1): 57-73. https://doi. org/10.1007/s11056-004-6794-5

Ibironke, O. A. and Victor, O. O. 2016. Effect of media and growth hormones on the rooting of Queen of Philippines (Mussaenda philippica). J Hortic 3: 173. doi:10.4172/2376-0354.1000173

Ibrahim, M. E., Mohamed, M. A. and Khalid, K. A. 2015. Effect of plant growth regulators on rooting of lemon verbena cuttings. Material and Environmental Science 6 (1): 28-33.

Ingram, D. L., Henley, R. W. and Yeager, T. H. 1993. Growth Media for Container Grown Ornamental Plants. Environmental Horticulture Department, Florida Cooperative Extension Service, Institute of Food and Agricultural Sciences, University of Florida, Florida, USA.

Jacygrad, E., Ilczuk, A, Mikos, M. and Kubiec, K.
J. 2012. Effect of medium type and plant growth regulators on the in vitro shoot proliferation of Cotinus coggygria Scop. Royal Purple. Acta Sci. Pol. Hortorum Cultus 11 (5): 143-151.

Kochhar, V. K., Singh, S. P., Katiyar, R. S. and Pushpangadan, P. 2005. Differential rooting and sprouting behavior of two Jatropha species and associated physiological and biochemical changes. Current Science 89 (6): 936-939.

Leakey, R., Newton, A. and Dick, J. 1994. Capture of genetic variation by vegetative propagation: processes determining success. In Tropical trees: the potential for domestication and the rebuilding of forest resources (eds.) Leakey, R. R. B., Newton, A. C . London, HMSO, 72-83.

Ludwig, M. J. 2000. Indole-3-butyric acid in plant growth and development. Plant Growth Regulator 32: 219-230. doi:10.1023/A:1010746806891

Mabizela, G. S., Slabbert, M. M. and Bester, C. 2016. The effect of rooting media, plant growth regulators and clone on rooting potential of honeybush (Cyclopia subternata) stem cuttings at different planting dates. 110: 75-79. South African Journal of Botany. http://dx.doi. org/10.1016/j.sajb.2016.02.200

Majeed, M., Khan, M. A., and Mughal, A. H. 2009. Vegetative propagation of Aesculus indica through stem cuttings treated with plant growth regulators. Journal of Forestry Research 20 (2): 171-173. https:// doi.org/10.1007/s11676-009-0031-1

Manandhar, N. P. 2002. Plants and People of Nepal. Timber Press: Portland, Oregon, USA.

Nair, K. N. and Nayar, M. P. 1997. Flora of India. Vol. 4 (Malpighicear - Dichapetalaceae). (P. Hajra, P. K., Nair, V. J. and Daniel, Eds.). Botanical Survey of India, Calcutta.

Phuyal, N., Jha, P. K., Raturi, P. P. and Rajbhandary, S. 2019. Zanthoxylum 
armatum DC.: Current knowledge, gaps and opportunities in Nepal. Journal of Ethnopharmacology 229: 326-341. doi:10.1016/j.jep.2018.08.010.

Poupard, C., Chauviere, M. and Monteuuis, O. 1994. Rooting Acacia mangium cuttings: Effects of age, within-shoot position and auxin treatment. Silvae Genetica 43 (4): 226-230.

Schmitz, D., Anlauf, R., and Rehrmann, P. 2013. Effect of air content on the oxygen diffusion coefficient of growing media. American Journal of Plant Sciences 4: 955-963.

Sevik, H. and Guney, K. 2013. Effects of IAA, IBA, NAA, and GA3 on rooting and morphological features of Melissa officinalis L. stem cuttings. The Scientific World Journal. Vol. 2013, Article ID 909507, 1-5. http://dx.doi. org/10.1155/2013/909507.

Sharma, L. K and Pandey, O. N. 1999. Effect of plant growth regulators on rooting behaviour of cuttings of Dalbergia latifolia Roxb. and Dalbergia sissoo Roxb. Indian Forester 125: 421-426.

Shameet, G. S., Khosla, P. K. and Kumar, S. 1989. A Preliminary study on rooting of Celtis australis and Punica granulatum cuttings. Indian Journal of Forestry 12 (4): 321-322.

Singh, B. and Rawat, J. M. S. 2017. Effects of cutting types and hormonal concentration on vegetativepropagation of Zanthoxylum armatum in Garhwal Himalaya, India. Journal of Forestry Research 28 (2): 419423. DOI 10.1007/s11676-016-0286-2

Singh, O. J., Raleng, I., Premchand, M., and Debashree, N. 2016. A review on the pharmacological profiles of Zanthoxylum armatum (Rutaceae). Journal of Evolution of Research in Medical Pharmacology. 2 (1): $10-12$.

Soundy, P., Mpati, K.W., du Toit, E. S., Mudau, F. N. and Araya, H. T. 2008. Influence of cutting position, medium, hormoneand season on rooting of fever tea (Lippia javanica L.) stem cuttings. Medicinal and Aromatic Plant Science and Biotechnology 2 (2): 114-116.

Strydem, D. K. and Hartman, H. T. 1960. Effect of indolebutyric acid and respiration and nitrogen metabolism in Marianna 2624 plum softwood stem cuttings. Proceedings of American Society of Horticulture 45 (12): 81-82.

Swamy, S. L., Puri, S., and Singh, A. K. 2002. Effect of auxins (IBA and NAA) and season on rooting of juvenile and mature hardwood cuttings of Robinia pseudoacacia and Grewia optiva. New Forests 23 (2): 143-157. https://doi. org/10.1023/A:1015653131706

Taiz, L. and Zeiger, E. 1998. Plant Physiology. 2nd edition. Sinauer AssociatesInc., Massachusetts, USA.

Tara, J. S., Sudan, M., and Sharma, B. 2011. A report on the occurrence of insect pests on Zanthoxylum armatum DC (Family: Rutaceae), an important medicinal plant in Jammu region. The Bioscan 6 (2): 223228.

Tchoundjeu, Z., Duguma, B., Tiencheu, M. and Ngo-Mpeck, M., 1998. The domestication of indigenous agroforestry trees: ICRAF's strategy in the humid tropics of West and Central Africa. In Current Research Issues and Prospects for Conservation and Development (eds.) Sunderland, T.C.H., Clark, L. E. and Vantomme, P. FAO.

Tchoundjeu, Z., Avana, M. L., Leakey, R. R. B., Simons, A. J., Assah, E., Duguma, B., and Bell, J. M. 2002. Vegetative propagation of Prunus africana: Effects of rooting medium, auxin concentrations and leaf area. Agroforestry Systems. 54 (3): 183-192. https://doi.org/10.1023/A:1016049004139.

Tchoundjeu, Z., Ngo Mpeck, M. L., Asaah, E. and Amougou, A. 2004. Therole of vegetative propagation in the domestication of Pausinystalia johimbe (K. Schum), a highly threatened medicinal speciesof 
West and Central Africa. Forest Ecology and Management 188:175-183.

Thakur, L., Gupta, T. and Kumar, R. 2018. Effect of growth regulators on sprouting and rooting behaviour in cuttings of Acacia catechu Willd. and Toona ciliata M. Roem. Journal of Pharmacognosy and Phytochemistry SP1: 109-114.

Usman, I. A and Akinyele, A. O. 2015. Effects of growth media and hormones on the sprouting and rooting ability of Massularia acuminata (G. Don) Bullock ex Hoyl. Journal of Research in Forestry, Wildlife \& Environment 7 (2): 137-146.

Wojtusik, T., Boyd, M. T. and Felker, P. 1994. Effect of different media on vegetative propagation of Prosopis juliflora cuttings under solar-powered mist. Forest Ecology and Management 67 (1-3): 267-271. 